\title{
Effect of Saccharomyces cerevisiae and Spirulina platensis on Suppressing Root-knot Nematode, Meloidogyne incognita Infecting Banana Plants under Greenhouse Conditions
}

\author{
Ragaa, A. Hamouda ${ }^{1,4}$; Mahmoud A. Al-Saman ${ }^{2}$ and Mostafa, S. M. El-Ansary ${ }^{3}$ \\ ${ }^{1}$ Dept. Microbial Biotechnol.; ${ }^{2}$ Dept. Industrial Biotechnol., ${ }^{3}$ Dept. Plant Biotechnol., \\ Genet. Eng. Biotechnol. Res. Inst. (GEBRI), Univ. Sadat City, \\ Sadat City, Egypt \\ ${ }^{4}$ Dept. Biology, Fac. Sci. and Arts, Khulais, Univ. Jeddah, Saudi Arabia
}

Corresponding author email: mostafa.el-ansary@gebri.usc.edu.eg and mosansary71@yahoo.com

\begin{abstract}
Banana production is severely hindered by plant-parasitic nematodes (PPNs) worldwide. Chemical nematicide, oxamyl is a systematic compound widely applied for the control of PPNs. Because of increase pests' problems, harmful effects on human and environment caused by chemical pesticides and also increased consumer requirements for safe crops have encouraged research on bio-pesticides production. So, the effect of different stress of the yeast, Saccharomyces cerevisiae and blue green algae (cyanobacteria), Spirulina platensis were examined on banana plants infected with root-knot nematodes, Meloidogyne incognita. All tested treatments were effective methods to manage $M$. incognita in soil samples and banana roots. Notably, the usage of $S$. cerevisiae and $S$. platensis in combination treatment revealed the greater antagonistic action on $M$. incognita in potted banana. In addition it has an avail advantage over artificial nematicides by having several means to attack the RKN and mainly enhanced plant growth compared to any other treatments. Yet, the previous treatment had increased catalase (CAT) enzyme activity and reduced pectin methyl esterase (PME) activity in banana plant that leads to inhibit the count of the RKN. Generally, our results supply a novel knowledge to understand of PPNs management as a new approach for applying bio-fertilizer and bio-control of the parasitic nematodes.
\end{abstract}

Keywords: RKN, Meloidogyne incognita, banana, yeast, cyanobacteria, PME, CAT, bio-control.

\section{Introduction}

Bananas (Musa spp.) are planted as a main crop in many tropical and sub-tropical countries (De la Torre-Gutierrez et al., 2008). Plantain crop production is affected by many pathogenic and non-pathogenic agents (Rahman et al., 2010; Gamliel and van Bruggen, 2016), especially plant-parasitic nematode (PPN) that cause rhizome damage leads to reduce water, micro and macro-nutrient compounds uptake (Moens et al., 2004; Mwauraa et al., 2017), resulting in decreased growth criteria, yield and 
finally plant death (Karssen et al., 2013). Many synthetic nematicides actually used to inhibit PPN, have created to possess highly toxicity affecting human health and environment (Gupta, 2011; Rani et al., 2017). Therefore, the use of these components have created undesirable effects, high costs and restrictive (Rockström et al., 2016). Hence, it is remarkable to discover an effective alternative methods to include safety food production and environmentally ecofriendly crop production (Naz et al., 2016). Applicability of some yeasts are used for controlling fungal diseases on fruits (Nally et al., 2012; Pesce et al., 2018), and also using as bio-control agents for post-harvest diseases of many crops (Punja 1997; da Cunha et al., 2018). In a similar study by Karajeh, 2013, high concentration of total phenolics compounds in roots of some yeasts-treated plants and hydrogen peroxide $\left(\mathrm{H}_{2} \mathrm{O}_{2}\right)$-treated plants provides a sign on the function of the yeast to induce resistance of the plants against pests. In addition the yeasts are considered as a natural enhancement of plant growth due to presence of compounds such as cytokinin and tryptophan, which playing an important role in plant cell division (Nassar et al., 2005; El-Tarabily and Sivasithamparam, 2006; Ignatovaa et al., 2015). In contrast, application of some cyanobacteria (blue green algae) in soil may inhibit PPN infestation (Chandel, 2009; Holajjer et al., 2012) by producing hydrolytic enzymes and secondary metabolites called cyanotoxins (Gupta et al., 2013). For example, stimulation of plant defense occurs by producing of both hydrolytic enzymes and anti-microbial metabolites (Babu et al., 2015). Microalgae, especially cyanobacteria have abilities of the atmospheric nitrogen fixationas a good biofertilizers (Prasanna et al., 2013; Hamouda and El-Ansary, 2017; El-Ansary and Al-Saman, 2018), due to of some mineral nutrient compounds in cynobacteria (Faheed and El-Fattah, 2008; Rana et al., 2012; Prasanna et al., 2016). Notable, Spirulina platensis have a vigorous inhibitor on root-knot nematodes (RKN) and also possess a powerful stimulating effect on the plant growth (Sharaf et al., 2016). A novel study based on yeast and cyanobacteria for controlling the RKN, Meloidogyne incognita through potted banana, was conducted.

\section{MATERIALS AND METHODS}

\section{Nematode analysis}

Eggs of Meloidogyne incognita were extracted from pure culture propagated on tomato (Solanum lycopersicum cv. Castle Rock) roots infected with the nematode using sodium hypochlorite, NaOcl solution (Hussey and Barker, 1973). Second-stage juveniles $(\mathrm{J} 2 \mathrm{~s})$ were collected daily from eggs and were stored at $15^{\circ} \mathrm{C}$. The $\mathrm{J} 2 \mathrm{~s}$ used in the experiments were less than 5 days old.

\section{Yeast preparation}

Saccharomyces cerevisiae (SH02) was obtained from Microbiology Lab of the Genetic Engineering and Biotechnology Research Institute (GEBRI), University of Sadat City, Sadat City, Egypt. One gram of S. cerevisiae was inoculated in $200 \mathrm{ml}$ YPD medium (Yeast extract peptone dextrose $-1 \%$ yeast extract, 2\%peptone, $2 \%$ glucose, $2 \%$ agar, $0.01 \%$ ampicillin, and $0.01 \%$ nalidixic acid dissolved in $1 \mathrm{~L}$ of distilled water) under sterilized conditions and incubated at $30^{\circ} \mathrm{C}$ for 24 (Azeredo et al., 1998). The culture was centrifuged for $5 \mathrm{~min}$ at $5000 \mathrm{rpm}$ and washed two times with sterilized distilled water then the pellets were collected and dried in oven until constant weight. 


\section{Algal preparations}

Blue green algae (Cyanobacteria), Spirulina platensis were obtained from Microbiology Lab of the GEBRI. S. platensis $(15 \mathrm{ml})$ was inoculated in $100 \mathrm{ml}$ Zarrouk medium (Zarrouk, 1966) at $25 \pm 1^{\circ} \mathrm{C}$ with continuous illumination using cool white fluorescent tubes (2500 Lux). Cells were collected by filtration using filter paper and was washed with distilled water and then dried in oven.

\section{Treatments}

The treatments are used at the following: A, S. cerevisiae $(1 / 2 \mathrm{~S}=2 \mathrm{~g} / 4 \mathrm{~kg}$ soil $) ; \mathbf{B}, S$. cerevisiae $(\mathrm{S}=4 \mathrm{~g} / 4 \mathrm{~kg}$ soil $) ; C$, S.platensis $(1 / 2 \mathrm{~S}=2 \mathrm{~g} / 4 \mathrm{~kg}$ soil $) ; D$, S. platensis $(\mathrm{S}=$ $4 \mathrm{~g} / 4 \mathrm{~kg}$ soil), E, S. cerevisiae $(1 / 2 \mathrm{~S})+$ S. platensis $(1 / 2 \mathrm{~S})$, F, Nematicides check, Oxamyl (Vydate 24\% L); G, Check with infection; H, Check without infection.

\section{Greenhouse infection assay}

Two months old banana plants cv. Grande-Naine were obtained from the Tissue Culture Lab of the GEBRI. Plantlets were planted in $30 \mathrm{~cm}$ diameter plastic pots containing about $4.0 \mathrm{~kg}$ of sterilized soil (1:3 mixture of clay: sand) with $\mathrm{pH} 7$. Twenty pots were treated with previous treatments after preparation, with treatment "A" and "C" in concentration of $2 \mathrm{~g} / 4 \mathrm{~kg}$ soil; treatment "B" and "D" in concentration of $4 \mathrm{~g} / 4 \mathrm{~kg}$ soil; and finally No. " $\mathrm{E}$ " is a mixture between "A" and "C". Four number of inoculated pots was treated with $1 \mathrm{ml}$ of oxamyl (nematicies check) per pot. Bananas were treated by current applications every month for two month. The remaining four inoculated pots served as inoculated and untreated-nematode control (check with infection). Moreover, four more pots served as control without nematode (check). The tested materials were added to the soil in 3 holes around the plantlet and followed by the addition of $50 \mathrm{ml}$ of water. The pots were arranged in a completely randomized design in a greenhouse of the GEBRI. Plants were evaluated after 60 days of inoculation. The roots were washed carefully by tap water to remove the soil particles and then stained with Phloxine B $(3.5 \mathrm{~g}$ in $750 \mathrm{ml}$ distilled water $+250 \mathrm{ml}$ acetic acid $5 \%$ ) solution for 5 min to facilitate counting of females and egg masses in the root. Nematode variables observed per the total root weight were galls, females and egg masses. Also, juveniles per $250 \mathrm{~g}$ soil were extracted according to Cobb's sieving and decanting method, using sieves (60 mesh and 325 mesh) (Cobb, 1918). The banana growth variables shoot and root length $(\mathrm{cm})$; also shoot, root and corm fresh weight (g) were also recorded.

\section{Determination of enzyme activities}

One gram of banana tissue leaves was homogenized in $20 \mathrm{ml}$ of $50 \mathrm{mM}$ potassium phosphate buffer (ppb), $\mathrm{pH} 7.0$ at $25^{\circ} \mathrm{C}$. These triturated tissues were removed through four layers of cheese cloth and the filtrate was centrifuged at 20,000 rpm at $4{ }^{\circ} \mathrm{C}$ for 15 min. The supernatant served as an enzyme extract for enzyme assay of catalase and pectin methyl esterase using the UV-Vis spectrophotometer (Shimadzu CorporationMultiSPec-1501).

\section{A- Catalase (CAT) activity}

The CAT activity was determined according to the method given by Beers and Sizer (1952). The reaction mixture was formed by mixing $2.90 \mathrm{ml}$ of hydrogen peroxide solution $0.036 \%(\mathrm{w} / \mathrm{w})$ in phosphate buffer (the absorbance of the solution 
should be about 0.5 absorbance units at $240 \mathrm{~nm}$ ) to $0.1 \mathrm{ml}$ of enzyme solution. The time required for the $\mathrm{A}_{240}$ to decrease from 0.45 to 0.40 absorbance units was recorded. Catalase activity was calculated as: Units/ml enzyme $=(3.45) *(\mathrm{df}) /(\mathrm{t}) *(0.1)$

\section{Where:}

$3.45=$ corresponds to the decomposition of $3.45 \mu$ moles of hydrogen peroxide in a 3.0 $\mathrm{mL}$ reaction mixture producing a decrease in the $\mathrm{A}_{240}$ from 0.45 to 0.40

$\mathrm{df}=$ dilution factor

$\mathrm{t}=\min (\mathrm{s})$ required for the $\mathrm{A}_{240}$ to decrease from 0.45 to 0.40 absorbance units

$0.1=$ enzyme solution volume

\section{B- Pectin methyl esterase (PME) activity}

The PME activity was determined according to the continuous spectrophotometric method given by Hagerman and Austin (1986). The reaction mixture was formed by mixing $2.3 \mathrm{ml}$ of $0.3 \%$ pectin solution in $0.1 \mathrm{M} \mathrm{NaCl}, 0.5 \mathrm{ml}$ of $0.01 \%$ of bromothymol blue in $3 \mathrm{mM}$ sodium phosphate buffer $(\mathrm{pH} 7.5)$, and $0.1 \mathrm{~mL}$ of enzyme extract. The corresponding control sample contained enzyme extract obtained from untreated tissue.

The change in absorbance at $620 \mathrm{~nm}$ was monitored for $10 \mathrm{~min}$ in a UV/VIS spectrophotometer (UV-200-RSLW scientific) with a constant temperature working at $20^{\circ} \mathrm{C}$. PME activity was determined as units of absorbance $\min ^{-1}$ per $\mathrm{g}$ fresh tissue.

Units $=\left(\mathrm{Ab}_{(620)}\right.$ sample $/ \mathrm{Ab}_{(620)}$ control $) *(\mathrm{df}) /(\mathrm{t}) *(0.1)$

\section{Where:}

$\mathrm{df}=$ dilution factor; $\mathrm{t}=\min (\mathrm{s}) ; 0.1=$ enzyme solution volume

\section{Statistical analysis}

All data were subjected to analysis of variance (ANOVA) (Sokal and Rohlf, 1995). Significance of the variable mean differences was determined using Duncan's multiple range tests $(p \leq 0.05)$. All analyses were carried out using SPSS 16 software.

\section{RESULTS}

\section{Bio-nematicidal action}

Influence of the treatments on the RKN, M. incognita in banana plants resulted in a clear depression of the nematode numbers. Counts of galls, females and egg masses in the roots and second stages (juveniles2, $\mathrm{J} 2 \mathrm{~s}$ ) in the soil were recorded compared to the nematode check (check with infection) (Table 1). In general, all of the used applications stimulated the greatest curative results and significantly $(p \leq 0.05)$ inhibited the count of $\mathrm{J} 2 \mathrm{~s}$ in soil; galls, females and egg masses in root. With regard to "D" treatment exhibited the highest inhibition of nematodes numbers in soil $(84.51 \%$ reduction, \%R), while the lowest effective treatment in decreasing $\mathrm{J} 2 \mathrm{~s}$ in soil was recorded in "A" treatment (74.93\% R) compared to "G" treatment (nematode check). No significant differences were achieved among "B", "C" and "E" treatments in number of galls and recovered parasitic stages in roots (Fig. 1). 
Table 1. Numbers of Meloidogyne incognita in soil and root samples under different stresses of the yeast Saccharomyces cerevisiae and cyanobacteria, Spirulina platensis.

\begin{tabular}{|c|c|c|c|c|}
\hline \multirow{2}{*}{ Treatments } & \multicolumn{3}{|c|}{ Count per the total root weight } & \multirow{2}{*}{$\begin{array}{l}\text { Count per } \\
250 \text { g soil } \\
\text { Juveniles } 2\end{array}$} \\
\hline & Galls & Females & Egg masses & \\
\hline A & $471.37 \mathrm{~d}$ & $452.10 \mathrm{c}$ & $369.15 c$ & $1728.75 \mathrm{c}$ \\
\hline B & $382.37 \mathrm{~cd}$ & $391.52 b c$ & $333.48 b c$ & $1227.5 b$ \\
\hline $\mathrm{C}$ & $296.11 b c$ & $363.64 b c$ & $311.85 b c$ & $1674.5 \mathrm{c}$ \\
\hline $\mathrm{D}$ & $279.49 b c$ & $308.72 \mathrm{ab}$ & $239 b$ & $1067.75 b$ \\
\hline $\mathrm{E}$ & $231.28 \mathrm{ab}$ & $257.55 \mathrm{ab}$ & $299.04 b c$ & $1115.25 b$ \\
\hline $\mathrm{F}$ & $153.45 \mathrm{a}$ & $186.79 \mathrm{a}$ & $122.51 \mathrm{a}$ & $767.25 a$ \\
\hline G & $912.38 \mathrm{f}$ & $1054.08 \mathrm{~d}$ & $897.31 d$ & $6895 d$ \\
\hline
\end{tabular}

Means followed by the same letter(s) within a column are not significantly different $(p \leq 0.05)$ according to Duncan's multiple range test. Each value represents means of four replicates.

$\mathrm{A}=S$. cerevisiae $(1 / 2 \mathrm{~S}=2 \mathrm{~g} / 4 \mathrm{~kg}$ soil $) ; \mathrm{B}=S$. cerevisiae $(\mathrm{S}=4 \mathrm{~g} / 4 \mathrm{~kg}$ soil $) ; \mathrm{C}=$ S. platensis $(1 / 2 \mathrm{~S}=2 \mathrm{~g} / 4 \mathrm{~kg}$ soil $) ; \mathrm{D}=S$. platensis $(\mathrm{S}=4 \mathrm{~g} / 4 \mathrm{~kg}$ soil $), \mathrm{E}=$ S. cerevisiae $(1 / 2 \mathrm{~S})+$ S. platensis $(1 / 2 \mathrm{~S}), \mathrm{F}=$ Oxamyl (Vydate $24 \% \mathrm{~L}) ; \mathrm{G}=\mathrm{Check}$ with infection.

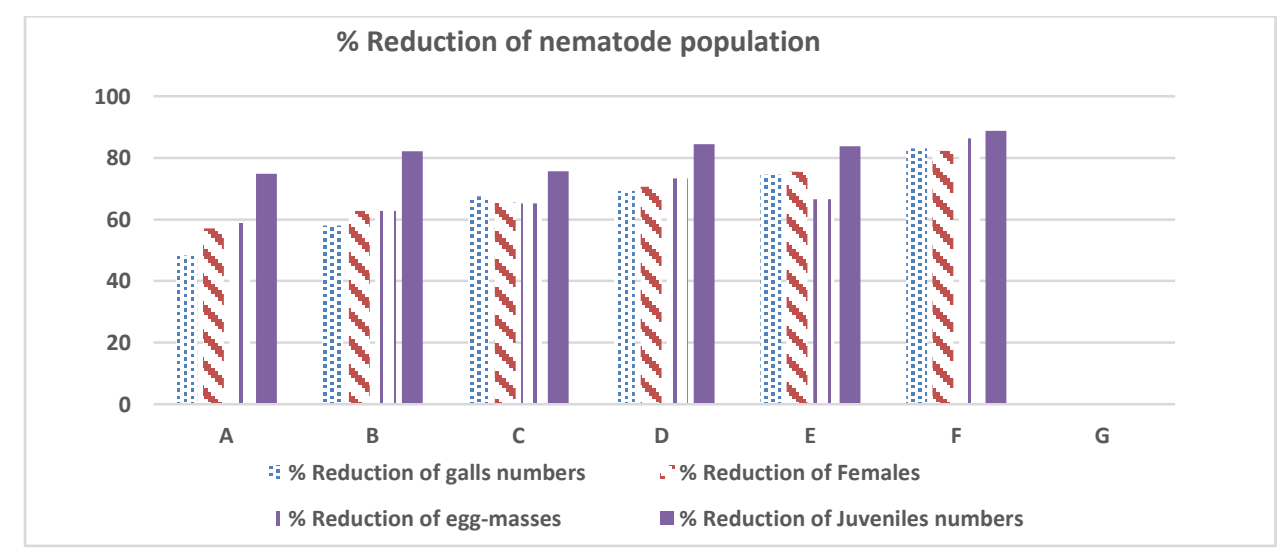

Fig. 1. Incidence (\%) of nematode counts after application with different stresses of yeast and cyanobacteria.

$\mathrm{A}=S$. cerevisiae $(1 / 2 \mathrm{~S}=2 \mathrm{~g} / 4 \mathrm{~kg}$ soil $) ; \mathrm{B}=S$. cerevisiae $(\mathrm{S}=4 \mathrm{~g} / 4 \mathrm{~kg}$ soil $) ; \mathrm{C}=$ S. platensis $(1 / 2 \mathrm{~S}=2 \mathrm{~g} / 4 \mathrm{~kg}$ soil $) ; \mathrm{D}=$ S. platensis $(\mathrm{S}=$ $4 \mathrm{~g} / 4 \mathrm{~kg}$ soil $), \mathrm{E}=$ S. cerevisiae $(1 / 2 \mathrm{~S})+\mathrm{S}$. platensis $(1 / 2 \mathrm{~S}), \mathrm{F}=$ Oxamyl $($ Vydate $24 \% \mathrm{~L})$.

$\%$ Reduction= percent reduction compared with nematode only (check with infection)

\section{Evaluation of banana growth criteria}

Growth parameters of tested plants i.e., weight and length of shoots and roots and weight of corms are listed in Table (2). All tested applications as well as control without infection enhanced slightly plant health with no significant differences compared to control ( $\mathrm{G}$ treatment). Notable, the greatest outcome on the all plant 
measurements was given by treatment "E". Relatively, the treatment "B" had lesser effect in increasing corm weight and shoot length compared to " $F "$ treatment. No notable increase in root weight measurements was commented

Table 2. Effect of different stresses of Saccharomyces cerevisiae and Spirulina platensis on banana growth infected with Meloidogyne incognita.

\begin{tabular}{|c|c|c|c|c|c|}
\hline \multirow{2}{*}{ Treatments } & \multicolumn{2}{|c|}{ Shoot } & \multicolumn{2}{c|}{ Root } & Corm \\
\cline { 2 - 6 } & Length & Weight & Length & Weight & Weight \\
\hline A & $42.25 \mathrm{ab}$ & $33.62 \mathrm{~b}$ & $13.25 \mathrm{a}$ & $12.21 \mathrm{a}$ & $13.65 \mathrm{a}$ \\
\hline $\mathrm{B}$ & $41.25 \mathrm{ab}$ & $36.73 \mathrm{~b}$ & $17.00 \mathrm{a}$ & $9.83 \mathrm{a}$ & $11.23 \mathrm{a}$ \\
\hline $\mathrm{C}$ & $48.00 \mathrm{ab}$ & $41.63 \mathrm{~b}$ & $11.25 \mathrm{a}$ & $8.75 \mathrm{a}$ & $14.45 \mathrm{a}$ \\
\hline $\mathrm{D}$ & $44.75 \mathrm{ab}$ & $44.11 \mathrm{~b}$ & $28.00 \mathrm{ab}$ & $18.67 \mathrm{a}$ & $17.06 \mathrm{ab}$ \\
\hline $\mathrm{E}$ & $49.00 \mathrm{ab}$ & $51.86 \mathrm{~b}$ & $15.00 \mathrm{a}$ & $22.06 \mathrm{a}$ & $32.41 \mathrm{ab}$ \\
\hline $\mathrm{F}$ & $42.00 \mathrm{ab}$ & $38.73 \mathrm{~b}$ & $17.25 \mathrm{ab}$ & $10.53 \mathrm{a}$ & $13.23 \mathrm{a}$ \\
\hline $\mathrm{G}$ & $39.50 \mathrm{a}$ & $29.25 \mathrm{a}$ & $18.50 \mathrm{ab}$ & $16.14 \mathrm{a}$ & $11.29 \mathrm{a}$ \\
\hline $\mathrm{H}$ & $50.00 \mathrm{~b}$ & $50.26 \mathrm{~b}$ & $20.25 \mathrm{ab}$ & $27.19 \mathrm{a}$ & $43.08 \mathrm{~b}$ \\
\hline
\end{tabular}

Means followed by the same letter(s) within a column are not significantly different $(p \leq 0.05)$ according to Duncan's multiple range test. Each value represents means of four replicates.

$\mathbf{A}=S$. cerevisiae $(1 / 2 \mathrm{~S}=2 \mathrm{~g} / 4 \mathrm{~kg}$ soil $) ; \mathbf{B}=S$. cerevisiae $(\mathrm{S}=4 \mathrm{~g} / 4 \mathrm{~kg}$ soil $) ; \mathbf{C}=$ S. platensis $(1 / 2 \mathrm{~S}=2 \mathrm{~g} / 4 \mathrm{~kg}$ soil $) ; \mathbf{D}=S$. platensis $(\mathrm{S}=4 \mathrm{~g} / 4 \mathrm{~kg}$ soil $), \mathbf{E}=$ S. cerevisiae $(1 / 2 \mathrm{~S})+$ S. platensis $(1 / 2 \mathrm{~S}), \mathbf{F}=$ Oxamyl $($ Vydate $24 \% \mathrm{~L}) ; \mathbf{G}=$ Check with infection; $\mathbf{H}=$ Check without infection.

\section{Activity of catalyze (CAT) and pectin methyl esterase (PME) enzymes to depress RKNs, M. incognita}

The data presented in Figure (2), demonstrate that all applications increased the CAT enzyme especially in the "E" treatment. Consequently, it is obvious that increasing the activity of CAT enzyme had inhibited the count of $\mathrm{J}_{2} \mathrm{~S}$ in soil; galls, females and egg-masses of the RKN, M. incognita in banana plants. Likewise the same "E" treatment had efficiently increased plant growth. In general the highest CAT activity $(3081.5 \mu / \mathrm{g})$ was obtained in "E" treatment, while the least enzyme activity was recorded in "A" treatment $(1997.66 \mu / \mathrm{g})$ as compared to check with infection, "G" (1738 $\mu / \mathrm{g})$.

Also, the data presented in Figure (3), revealed that the activity of PME was in parallel with the infection severity where the PME activity increased with the increasing of nematode infection severity. "G" treatment (check with nematode) had the highest PME with averages of $0.49 \Delta \mathrm{Abs} \mathrm{min}^{-1}$. At the same time both "E" and "G" treatments had the least PME activity with averages of 0.28 and 0.31 $\Delta$ Abs min $^{-1}$, respectively. 


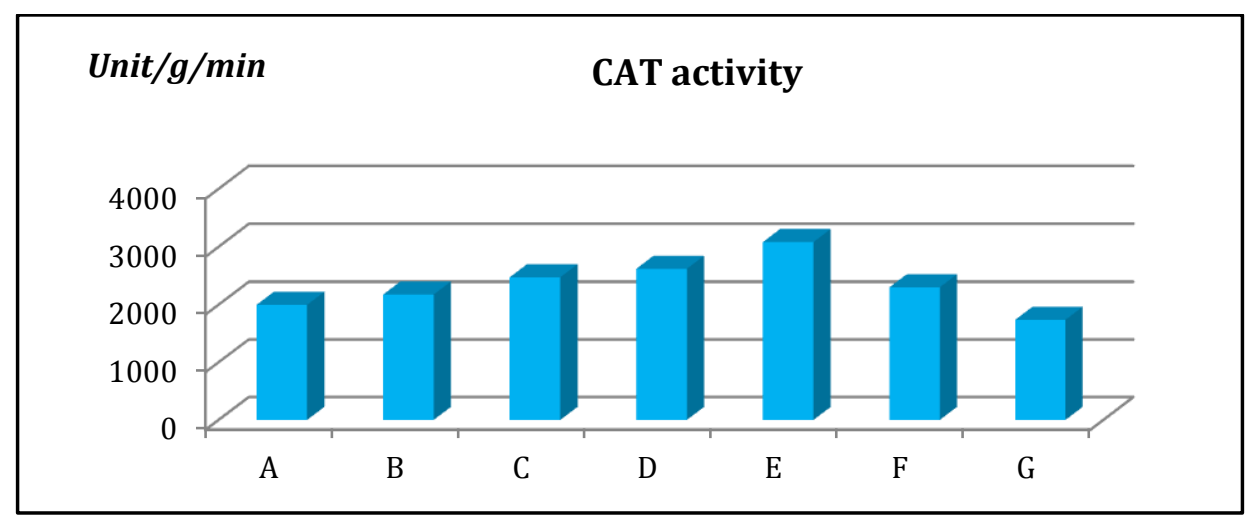

Fig. 2. Activity of CAT in banana plant as affected by RKN infection and applications of yeast, Saccharomyces cerevisiae and cyanobacteria, Spirulina platensis

$\mathrm{A}=S$. cerevisiae $(1 / 2 \mathrm{~S}=2 \mathrm{~g} / 4 \mathrm{~kg}$ soil $) ; \mathrm{B}=S$. cerevisiae $(\mathrm{S}=4 \mathrm{~g} / 4 \mathrm{~kg}$ soil $) ; \mathrm{C}=$ S.platensis $(1 / 2 \mathrm{~S}=2 \mathrm{~g} / 4 \mathrm{~kg}$ soil $) ; \mathrm{D}=S$. platensis $(\mathrm{S}=4 \mathrm{~g} / 4 \mathrm{~kg}$ soil $), \mathrm{E}=$ S. cerevisiae $(1 / 2 \mathrm{~S})+$ S. platensis $(1 / 2 \mathrm{~S}), \mathrm{F}=$ Oxamyl $($ Vydate $24 \% \mathrm{~L}) ; \mathrm{G}=\mathrm{Check}$ with infection.

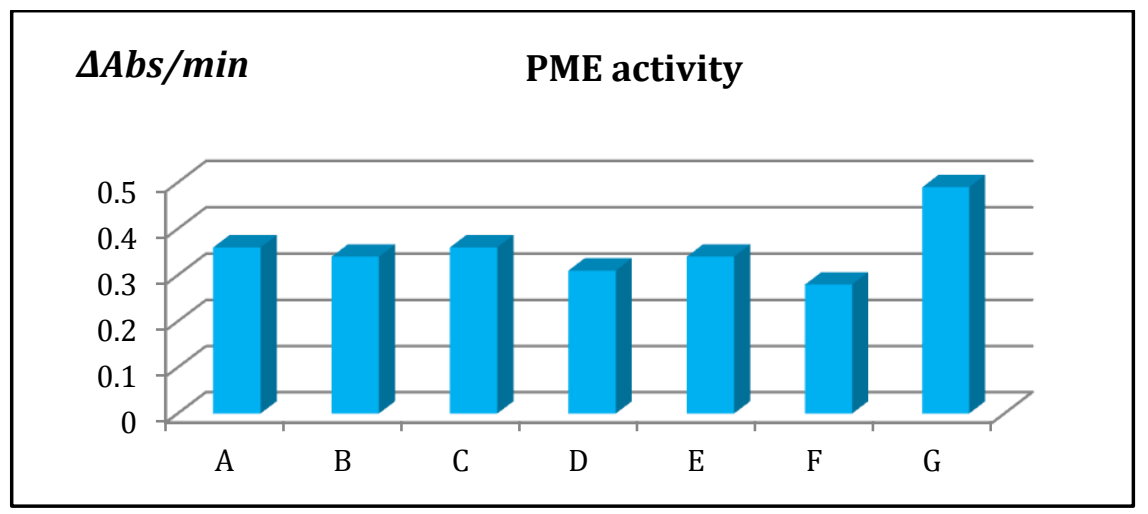

Fig. 3. Activity of MPE in banana plant as affected by RKN infection and applications of yeast, Saccharomyces cerevisiae and cyanobacteria, Spirulina platensis

$\mathrm{A}=S$. cerevisiae $(1 / 2 \mathrm{~S}=2 \mathrm{~g} / 4 \mathrm{~kg}$ soil $) ; \mathrm{B}=S$. cerevisiae $(\mathrm{S}=4 \mathrm{~g} / 4 \mathrm{~kg}$ soil $) ; \mathrm{C}=$ S. platensis $(1 / 2 \mathrm{~S}=2 \mathrm{~g} / 4 \mathrm{~kg}$ soil $) ; \mathrm{D}=S$. platensis $(\mathrm{S}=4 \mathrm{~g} / 4 \mathrm{~kg}$ soil $), \mathrm{E}=$ S. cerevisiae $(1 / 2 \mathrm{~S})+$ S. platensis $(1 / 2 \mathrm{~S}), \mathrm{F}=$ Oxamyl $($ Vydate $24 \% \mathrm{~L}) ; \mathrm{G}=\mathrm{Check}$ with infection.

\section{DISCUSSION}

\section{Antagonistic effects of the yeast and cyanobacteria on nematode development}

Many chemical nematicides used to control PPNs, have undesirable effects, high costs and restrictive (Crow, 2005; Rockstrom et al., 2016). So, yields production is required to make natural compounds affecting pathogenic pests, especially PPNs in many crops. In this study, we have tested the effect of different stress of yeast- $S$. cerevisiae and cyanobacteria, $S$. platensis compared to the nematicides check, oxamyl against RKN, $M$. incognita in banana plants. In general, counts of $M$. incognita in the soil, J2s and in the roots, females and egg-masses as well as galls per root were significantly inhibited compared to the check with nematode infection. For instance, "D' treatment revealed the greatest inhibition of $\mathrm{J} 2 \mathrm{~s}$ number in soil $(84.51 \% \mathrm{R})$. In contrast, the lowest effective agent in reducing $\mathrm{J} 2$ s count in soil was "A" treatment (74.93\% R) compared with of "G" treatment (untreated check with nematode). Blue 
green algae (cyanobacteria), S. platensis have a potent inhibitor on RKN and possess powerful stimulating effect on the plant growth (Sharaf et al., 2016). Hence, cyanobacteria have some mechanisms for inhibiting the development of RKNs. For example, many forms of cyanobacteria are informed to create a large number of toxic compounds like, nodularins, microcystins, neurotoxins (Holajjer et al., 2013; Gaget et al., 2017) and benzoic acid which produced by microalgae (Uzaira et al., 2018). Cyanobacteria can also depress pathogenic agents by distraction of the cytoplasmic membrane and suppression of the protein creation (Swain et al., 2017). Furthermore, the effect of some yeasts on RKN might be due to the potency of these yeasts to change carbohydrates to produce ethyl alcohol and $\mathrm{CO}_{2}$ that are highly toxic to RKN (Azhar et al., 2017). The other mechanisms of yeast to control activity for pests may introduce competition for some nutrients, parasitism and may induce resistance in plants; and also make physical and chemical soil structures undesirable for pathogenic agents to grow (Zhou et al., 2018; da Cunhaa et al., 2018; Pesce et al., 2018). Consequently, the treatment with the yeast, S. cerevisiae could inhibit of RKNs community and galls formation on cucumber root through its effects on the nematode life cycle to induce plant resistance (Karajeh, 2013).

\section{Efficacy of the yeast and blue green algae on banana growth-promoting}

Relatively, most treatments with yeast, $S$. cerevisiae and cyanobacteria, $S$. platensis promoted banana growth and this impact was highest on shoots and corms than on roots. The maximum outcome on the all banana-growth developments was given by treatment "E". Many studies recorded that the plant girth may be enhanced by yeasts (El-Tarabily and Sivasithamparam 2006; Botha, 2011; Ignatovaa et al., 2015).Yeast produce an assortment of naturally active components such as phytohormones, enzymes and auxin groups (indole-3-acetic acid, IAA) that have effectual promoting affect the plant health and help to enhance their yield production (Nassar et al., 2005; Ignatova et al., 2015; Moller et al., 2016). Furthermore, enhancement of plant growth and development is due to, the blue green algae, cyanobacteria having some mineral nutrient compounds and some active compounds like, auxins and gibberellins groups which affect plant health (Rana et al., 2012; Prasanna et al., 2016). In addition some species of cyanobacteria have abilities of the nitrogen fixation as a biofertilizer to promote plant growth (Holajjer et al., 2013; Genuárioa et al., 2017; Raia et al., 2018).

\section{CAT and PME activities in banana plant diseased with RKN}

All tested applications on banana leaves, increased the activity CAT enzyme particularly in "E" treatment $(3081.5 \mu / \mathrm{g})$. Consequently, the highest CAT enzyme activity in the previous treatment inhibited the count of all nematode parameters in soil and plants. Our results match with previous studies in which CAT enzyme is responsible for scavenging the excess of reactive oxygen species (ROS) in plant cells (Das and Roychoudhury, 2014). In addition CAT plays a vital role in scavenging the toxicity of hydrogen peroxide $\left(\mathrm{H}_{2} \mathrm{O}_{2}\right)$ under nematode infection (Asada, 1992). In contrast the activity of PME was in parallel with the infection severity whereas the enzyme activity increased with increasing of nematode infection. For example, untreated infected plants had the highest PME with averages of $0.49 \Delta \mathrm{Abs} \mathrm{min}^{-1}$. While, "F" and "E" treatments had the least PME activities with average of 0.28 and $0.31 \Delta \mathrm{Abs} \mathrm{min}^{-1}$, respectively. Pectinolytic enzymes are a heterogeneous group of enzymes such as PMEs that catalyse the pectic substances present in plants releasing 
acidic pectins and methanol. These enzymes allow pectin hydrolysis during plant cell growth through the infection by pathogenic agents (Gainvors et al., 1994). So, PME play a crucial role during plant-pathogen interactions and affects plant resistance for diseases. Thorpe et al. (2014) reported that the carbohydrate binding module (CBM) in PPN interacts with a host PME and over expression of either CBM or the PME increased through infection by parasitic-nematode.

Overall, in conclusion, results of the current in vivo trial established the effect of different stresses of yeast, $S$. cerevisiae and cyanobacteria, S.platensis on banana plant diseased with RKN, M. incognita. All applications are effective methods to control RKN in soil samples and banana roots. The use of $S$. cerevisiae and $S$. platensis in combination as a treatment showed highly antagonistic action on $M$. incognita in potted banana. It also has an avail over chemical nematicides by having several means to attack the previous pest and mainly enhance plant health compared to any other treatments. In addition increasing of CAT enzyme activity and reducing of PME activity in banana plant as a result of the used applications had inhibited the count of the RKN, M. incognita. In general these results supply an extra extensive to understand of PPNs management as a new approach for applying bio-fertilizers and bio-control agents of the current pest.

\section{REFERENCES}

Asada, K. (1992). Ascorbate peroxidase a hydrogen peroxide-scavenging enzyme in plants. Physiol. Plantarum. 85: 235-241.

Azeredo, L.A.I.; Gomes, E.A.T.; Mendonça-Hagler, L.C. and Hagler, A.N. (1998). Yeast communities associated with sugarcane in Campos, Rio de Janeiro, Brazil. Int. Microbiol. 1: 205-208.

Azhar, S.H.M.; Abdullaa, R.; Jambo, S.A.; Marbawi, H.; Gansau, J.A. and Faik, A.A.M. (2017). Yeasts in sustainable bioethanol production: A review. Biochem Biophys. Rep. 10: 52-61.

Babu, S.; Bidyarani, N.; Chopra, P.; Monga, D.; Kumar, R.; Radha, P.; Kranthi, S.; Adak, A. and Saxena, A.K. (2015b). Evaluating microbe-plant interactions and varietal differences for enhancing biocontrol efficacy in root rot challenged cotton crop. Eur. J. Plant Pathol. 142: 345-362.

Beers, R.F. and Sizer, I.W. (1952). A spectrophotometric method for measuring the breakdown of hydrogen peroxide by catalase. J. Biol. Chem. 195 (1):133-140.

Botha, A. (2011). The importance and ecology of yeasts in soil. Soil Biol. Biochem. 43:1-8.

Chandel, S.T. (2009). Nematicidal activity of the cyanobacterium, Aulosira fertilissima on the hatch of Meloidogyne triticoryzae and Meloidogyne incognita. Arch. Phytopathol. Plant Protect. 42(1): 32-38.

Cobb, N.A. (1918). Estimating the nema population of the soil. Agric. Tech. Circ. Bur. Pl. Ind. U.S. Dep. Agric. 1. 48.

Crow, W.T. (2005). Alternatives to fenamiphos for management of plant-parasitic nematodes on bermudagrass. J. Nematol. 37: 477-482.

da Cunha, T.; Ferraz L.P.; Wehr, P.P. and Kupper, K.C. (2018). Antifungal activity and action mechanisms of yeasts isolates from citrus against Penicillium italicum. Int. J. Food Microbiol. 276: 20-27.

De la Torre-Gutierrez, L.; Chel-Guerrero, L.A. and Betancur-Ancona, D. (2008). Functional properties of square banana (Musa balbisiana) starch. Food Chem. 106: 1138-1144. 
Das, K. and Roychoudhury, A. (2014). Reactive oxygen species (ROS) and response of antioxidants as ROS-scavengers during environmental stress in plants. Frontiers in Environm. Sci. 2(53): 1-13.

El-Ansary, M.S.M. and Al-Saman, M.A. (2018). Appraisal of Moringa oleifera crude proteins for the control of root-knot nematode, Meloidogyne incognita in banana. Rendiconti Lincei. Scienze Fisiche e Naturali 29: 631-637.

El-Tarabily, K.A. and Sivasithamparam, K. (2006). Potential of yeasts as biocontrol agents of soil-borne fungal plant pathogens and as plant growth promoters. Mycoscience 47:25-35.

Faheed, F.A. and El-Fattah, Z.A. (2008). Effect of Chlorella vulgaris as bio-fertilizer on growth parameters and metabolic aspects of lettuce plant. J. Agric. \& Soc. Sci. 4: $165-169$.

Gaget, V.; Humpage, A.R.; Huang, Q.; Monis, P. and Brookes, J.D. (2017). Benthic cyanobacteria: A source of cylindrospermopsin and microcystin in Australian drinking water reservoirs. Water Res. 124: 454-464.

Gainvors, A.; Frézier, V.; Lemaresquier, H.; Lequart, C.; Aigle, M. and Belarbi, A. (1994). Detection of polygalacturonase, pectin-lyase and pectin-esterase activities in a Saccharomyces cerevisiae strain. Yeast 10(10):1311-1319.

Gamliel, A. and van Bruggen, A.H.C. (2016). Maintaining soil health for crop production in organic greenhouses. Sci. Hortic. 208: 120-130.

Genuárioa, D.B.; Vazb M.G.M.V. and de Melo, I.S. (2017). Phylogenetic insights into the diversity of homocytous cyanobacteria from Amazonian rivers. Mol. Phylogenet Evol. 116: 120-135.

Gupta, R.C. (2011). Introduction. In: Gupta, R.C. (Ed.), Toxicology of Organophosphate and Carbamate Compounds. Elsevier Academic Press, Burlington, MA pp. 3-4.

Gupta, V.; Ratha, S.K.; Sood, A.; Chaudhary, V. and Prasanna, R. (2013). New insights into the biodiversity and applications of cyanobacteria (blue-green algae)Prospects and challenges. Algal Res. 2 (2): 79-97.

Hagerman, A.E. and Austin, P.J. (1986). Continuous spectrophotometric assay for plant pectin methyl esterase. J Agric. Food Chem., 34(3):440-444.

Hamouda, R.A. and El-Ansary, M.S.M. (2017). Potential of plant parasitic control in banana plants by microalgae as a new approaches towards resistance. Egyptian J. Biol. Control 27(2): 165-172.

Holajjer, P.; Kamra, A.; Gaur, H.S. and Dhar, D.W. (2012). In vitro nematicidal activity of a terrestrial cyanobacterium, Synechococcus nidulans towards plantparasitic nematodes. Nematology 14: 85-92.

Holajjer, P.; Kamra, A.; Gaur, H.S. and Manjunath, M. (2013). Potential of cyanobacteria for biorational management of plant parasitic nematodes: A review. Crop Prot. 53: 147-151.

Hussey, R.S. and Barker K.R. (1973). A comparison of methods of collecting inocula of Meloidogyne spp., including a new technique. Plant Dis Rep. 57:10251028.

Ignatova, L.V.; Brazhnikova, Y.V.; Berzhanova, R.Z. and Mukasheva, T.D. (2015). Plant growth-promoting and antifungal activity of yeasts from dark chestnut soil. Microbiol Res. 175: 78-83

Karajeh, M.R. (2013).Efficacy of Saccharomyces cerevisiae on controlling the rootknot nematode (Meloidogyne javanica) infection and promoting cucumber growth and yield under laboratory and field conditions. Arch. Phytopathol. Plant Protect. 46 (20): 2492-2500. 
Karssen, G.; Wesemae, W. and Moens, M. (2013). Root-knot nematodes. In: Perry, R.N., Moens, M. (Eds.), Plant Nematology, second ed. CAB International, Wallingford, UK pp. 73-108.

Moens, T.; Araya, M.; Swennen, R. and Waele, D.D. (2004). Enhanced biodegradation of nematicides after repetitive applications and its effect on root and yield parameters in commercial banana plantations. Biol. Fert. Soils 39: 407414.

Moller, L.; Lerm, B and Botha, A. (2016).Interactions of arboreal yeast endophytes: an unexplored discipline. Fungal Ecol. 22: 73-82.

Mwauraa, P.; Nierea, B. and Vidal, S. (2017). Application of an entomopathogenic fungus (Beauveria bassiana) increases potato nematodes reproduction and potato tubers damage caused by Ditylenchus destructor and D. dipsaci. Biol. Control 115: 23-29.

Nally, M.C.; Pesce, V.M.; Maturano, Y.P.; Munoz, C.J.; Combina, M.; Toro, M.E.; de Figueroa, L.I. and Vazquez, F. (2012). Biocontrol of Botrytis cinerea in table grapes by non-pathogenic indigenous Saccharomyces cerevisiae yeasts isolated from viticultural environments in Argentina. Post. Biol. Technol. 64: 40-48.

Nassar, A.H.; EI-Tarabily, K.A. and Sivasithamparam, K. (2005). Promotion of plant growth by an auxinproducing isolate of the yeast Williopsis saturnus endophytic in maize (Zeamays L.) roots. Biol. Fertil. Soils. 42: 97-108.

Naz, I.; Abdulkafi, S.; Munir, I.; Ahmad, M.; Ali, A.; PalomaresRius, J. E. and Ahmad, I. (2016). Cis-and trans-protopinium, a novel nematicide, forthe ecofriendly management of root-knot nematodes. Crop Prot. 81: 138-144.

Pesce, M.V.; Nally, M.C.; Carrizo, G.P.; Rojo, C.; Pérez, B.A.; Toro, M.E.; Castellanos de Figueroa L.I. and Vazquez F. (2018). Antifungal activity of native yeasts from different microenvironments against Colletotrichum gloeosporioides on ripe olive fruits. Biol. Control 120: 43-51.

Prasanna, R.; Kanchan, A.; Kaur, S.; Ramakrishnan, B.; Ranjan, K.; Singh, M.C.; Hasan, M.; Saxena, A.K. and Shivay, Y.S. (2016). Chrysanthemum growth gains from beneficial microbial interactions and fertility improvements in soil under protected cultivation. Hortic. Plant J., 2(4): 229-239.

Prasanna, R.; Sharma, E.; Sharma, P.; Kumar, A.; Kumar, R.; Gupta, V.; Pal, R.K.; Shivay, Y.S. and Nain, L. (2013). Soil fertility and establishment potential of inoculated cyanobacteria in rice crop grown under non-flooded conditions. Paddy Water Environ. 11 (1): 175-183.

Punja, Z.K. (1997). Comparative efficacy of bacteria, fungi and yeasts as biological control agents for disease of vegetable crops. Can. J. Plant Pathol. 19:315-323.

Rahman, S.A.S.; Mohamed, Z.; Othman, R.Y.; Swennen, R.; Panis, B. and Waele, D.D. (2010). In planta PCR-based detection of early infection of plant-parasitic nematodes in the roots: a step towards the understanding of infection and plant defence. Eur. J. Plant. Pathol. 128: 343-351.

Rana, A.; Joshi, M.; Prasanna, R.; Shivay, Y.S. and Nain, L. (2012). Biofortification of wheat through inoculation of plant growth promoting rhizobacteria and cyanobacteria. Eur. J. Soil Biol. 50: 118-126.

Raia, P.K.; Raia, A.; Sharmab, N.K.; and Singh S. (2018). Study of soil cyanobacteria along a rural-urban gradient. Algal Res. 35: 142-151.

Rani, M.; Uma Shanker, U. and Jassal, V. 2017. Recent strategies for removal and degradation of persistent \& toxic organochlorine pesticides using nanoparticles: A review. J. Environ. Manage. 190: 208-222. 
Rockstrom, J.; Williams, J.; Daily, G.; Noble, A.; Matthews, N.; Gordon, L. and de Fraiture, C. (2016). Sustainable intensification of agriculture for human prosperity and global sustainability. Ambio. 1-14.

Sharaf, A.M.A.; Kailla, A.M.; Mohamed, S.; Attia, M.S. and Nofal, M.M. (2016). Evaluation of biotic and abiotic elicitors to control Meloidogyne incognita infecting tomato plants. Nature Sci. 14(11): 125-137.

Sokal, R.R and Rohlf, F.J. (1995). Biometry: The Principles and practice of statistics in biological research, 3rd edn. W.H. Freeman and Co. New York

Swain, S.S.; Paidesetty, S.K. and Padhy, R.N. (2017). Antibacterial, antifungal and antimycobacterial compounds from cyanobacteria. Biomed Pharmacother. 90: 760-776.

Thorpe, P.; Mantelin, S.; Cock, P.J.; Blok, V.C.; Coke, M.C.; Eves-van den Akker, S.; Guzeeva, E.; Lilley, C.J.; Smant, G.; Reid, A.J.; Wright, K.M.; Urwin, P.E. and Jones, J.T. (2014). Genomic characterisation of the effector complement of the potato cyst nematode Globodera pallid. BMC Genomics 15:923.

Uzaira, B.; Menaa F.; Khan, B.A.; Mohammad, F.V.; Ahmad, V.U.; Djeribi, R. and Menaa, B. (2018). Isolation, purification, structural elucidation and antimicrobial activities of kocumarin, a novel antibiotic isolated from actinobacterium Kocuria marina CMG S2 associated with the brown seaweed Pelvetia canaliculata. Microbiol. Res. 206: 186-197.

Zarrouk, C. (1966). Contribution a l'etude d'une cyanobacterie: influence de divers facteurs physiques et chimiques sur la croissance et la photosynthese de Spirulina maxima (Setchell et Gardner) Geitler. PhD thesis, University of Paris, France.

Zhou Y.; Li W.; Zeng J. and Shao Y. (2018). Mechanisms of action of the yeast Debaryomyces nepalensis for control of the pathogen Colletotrichum gloeosporioides in mango fruit. Biol. Control 123: 111-119. 


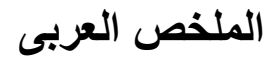

تاثير Spirulina platensis, Saccharomyces cerevisiae ونثبط نيماتودا تعقد الجذور من نوع Meloidogyne incognita والتى تصيب نباتات الموز تحت ظروف نيفائ الصوبة

رجاء أحمد حموده 4,1 ، محمود عبد الحميد السمان 2 ، مصطفى سيد مصطفى الأنصارى 3

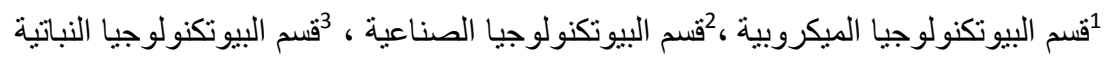

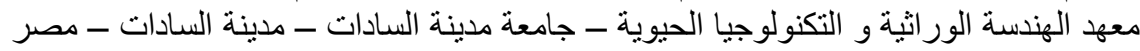

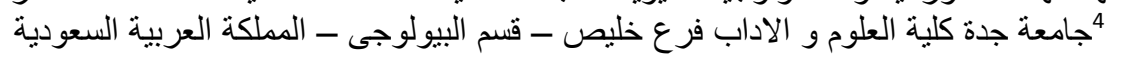

على المستوى العالمى فان عملية انتاج محصول الموز تتاثر كثيرا بخطورة النيماتودا المتطفلة على النبات. و حيث ان استخدام المبيدات الكيميائية النيماتودية و منها المركب الجهازى الأوكساميل و الذى يستخدم على نطاق واسع فى مقاومة النيماتودا. و بسبب انتشار الأفات و التاثثرات الضارة على كل من الانسان و البيئة من استخدام

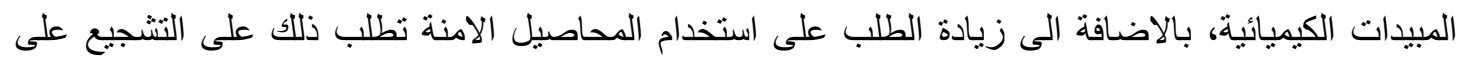

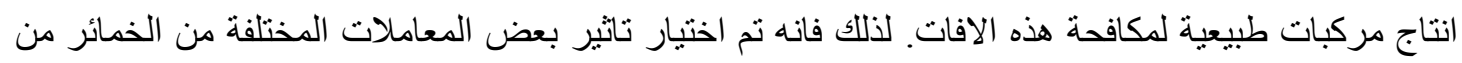
نوع S. cerevisiae و الطحالب الخضر اء المزرقة (السيانوبكتريا) من نوع S. platensis على نباتات الموز المصابة بنيماتودا تعقد الجذور من نوع M. incognita. أظهرت كل المعاملات المختبرة فاعليتها فى مكافحة و S. cerevisiae في كل من التربة و الجذور.جدير بالذكر أن المعاملة المكونة من مخلوط ال M. incognita تعكس رد فعل قوى ضد M. incognita platensis تمنللك تاثير و اضح عن المبيدات الكيميائية فى تثييطها على النيماتودا، انها أيضا لها القدرة على تحفيز نمو النبات مقارنة بالمعاملات الأخرى. علاوة على ذللك فان المعاملة السابقة تمتلك القدرة على زيادة تنشيط كل من انزيم الكتاليز و البكتين مثيل استيريز فى نبات الموز و الذى بدورة يؤدى الى تقليل أعداد نيماتودا. عموما فان النتائج

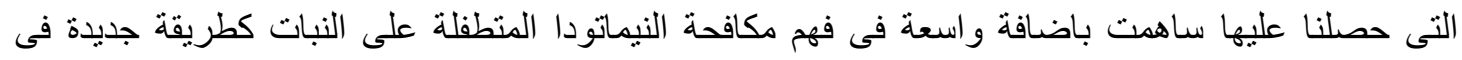
التسميد الحيوى و المكافحة الطبيعية ضد النيماتودا. 